\title{
Risk factors of platelet refractoriness in children
}

\author{
Jonliberti Purba ${ }^{1 *}$, Sri Mulatsih ${ }^{2}$, Neti Nurani2 ${ }^{2}$ Teguh Triyono ${ }^{3}$ \\ 'Sultan Sulaiman District Hospital, Serdang Bedagai District, North Sumatra, \\ 2Department of Pediatrics, ${ }^{3}$ Department of Clinical Pathology, Faculty of Medicine, \\ Universitas Gadjah Mada/Dr. Sardjito General Hospital, Yogyakarta, Indonesia
}

\begin{abstract}
Therapeutic platelet transfusions are often performed in pediatric patients with various indications. However, the platelet transfusion has potentially induced more harm than good for some patients. Therefore, its effectiveness needs to be evaluated. This study aimed to evaluate the clinical risk factors namely sepsis, splenomegaly, DIC (disseminated intravascular coagulation), severe bleeding and the history of platelet transfusion in the incidence of platelet refractoriness. This was a casecontrol study conducted over a 13-month period from August 1 1st, 2010 until September 30 $0^{\text {th }}, 2011$ in Department of Pediatrics, Dr. Sardjito General Hospital, Yogyakarta. From a total of 1403 platelet transfusion episodes in 464 patients, 86 incidences of refractoriness and 86 of nonrefractoriness were observed. Bivariate analysis showed that sepsis $[O R=5.91(2.90-12.05) ; p=0.000]$, splenomegaly $[O R=2.82(1.32-6.04) ; p=0.006]$, severe bleeding $[O R=8.41(4.19-16.871) ; p=$ $0.000]$, DIC [OR $=22.96(6.73-78.35) ; p=0.000]$ and the history of platelet transfusions [OR= $5.33(2.78-10.23) ; p=0.000]$ increased the risk of platelets refractoriness. Furthermore, multivariate analysis showed that sepsis $(\mathrm{OR}=2.96 ; 95 \% \mathrm{Cl}: 1.19-7.32 ; \mathrm{p}=0.019)$, splenomegaly $(\mathrm{OR}=3.94$; $95 \% \mathrm{Cl}: 2.21-16.00 ; \mathrm{p}=0.000)$, severe bleeding (OR $=3.53 ; 95 \% \mathrm{Cl}: 1.40-8.89 ; \mathrm{p}=0.008)$, DIC $(\mathrm{OR}=5.54 ; 95 \% \mathrm{Cl}: 1.29-22.75 ; \mathrm{p}=0.021)$ and the history of platelet transfusion $(\mathrm{OR}=2.84$; $95 \% \mathrm{Cl}: 2.74-9.77 ; \mathrm{p}=0.001$ ) were the independent risk factors for the occurrence of platelet refractoriness. In conclusion, sepsis, splenomegaly, severe bleeding, DIC, and the history of platelet transfusion are the risk factors of platelet refractoriness in pediatric patients.
\end{abstract}

\section{ABSTRAK}

Terapi transfusi trombosit sering dilakukan pada pasien anak dengan berbagai indikasi. Namun demikian transfusi trombosit mempunyai potensi menimbulkan bahaya dari pada manfaatnya. Oleh karena itu efektivitasnya perlu dievaluasi. Penelitian ini bertujuan untuk mengevaluasi faktor risiko klinik yaitu sepsis, splenomegali, DIC (disseminated intravascular coagulation), pendarahan berat dan riwayat transfusi trombosit pada kejadian refrakter trombosit. Penelitian ini merupakan penelitian kasus-kontrol yang dilakukan selama 13 bulan dari 1 Agustus 2010 sampai 30 September 2011 di Bagian Ilmu Kesehatan Anak, Rumah Sakit Umum Dr. Sardjito, Yogyakarta. Dari total 1403 episode transfusi trombosit pada 464 pasien, teramati 86 kejadian refrakter dan 86 tidak terjadi refrakter. Analisis bivariate menunjukkan bahwa sepsis $[O R=5,91(2,90-12,05) ; p=0,000]$, splenomegali $[O R=2,82(1,32-6,04) ; p=0,006]$, pendarahan berat $[O R=8,41(4,19-16,871) ; p=0,000]$, DIC $[O R=22,96(6,73-78,35) ; p=0,000]$ dan riwayat transfusi trombosit $[O R=5,33(2,78-10,23) ; p=$ $0,000]$ meningkatkan risiko refrakter trombosit. Analisis mulivariat selanjutnya menunjukkan bahwa sepsis (OR $=2,96 ; 95 \% \mathrm{Cl}: 1,19-7,32 ; \mathrm{p}=0,019)$, splenomegali (OR=3,94;95\% Cl: 2,21-16,00; $\mathrm{p}$ $=0,000)$, pendarahan berat (OR $=3,53 ; 95 \% \mathrm{Cl}: 1,40-8,89 ; \mathrm{p}=0,008)$, DIC (OR $=5,54 ; 95 \% \mathrm{Cl}$ : $1,29-22,75 ; p=0,021)$ dan riwayat transfusi trombosit (OR = 2,84;95\% Cl: 2,74-9,77; $\mathrm{p}=0.001$ ) merupakan faktor risiko independen terjadinya refrakter trombosit. Dapat disimpulkan bahwa sepsis, splenomegali, pendarahan berat, DIC dan riwayat transfusi trombosit merupakan faktor risiko terjadinya refrakter trombosit pada pasien anak.

Keywords: refractory platelets - $\mathrm{CCl}$ - number of platelets - children

\footnotetext{
* corresponding author: ijonliberti_purba@yahoo.com
} 


\section{INTRODUCTION}

Platelets are well known to have a large variety of functions. Platelets are main regulators of hemostasis where they contribute to the hemostatic plug and accelerate the coagulation system. ${ }^{1}$ Platelets also contribute to the pathogenesis of atherosclerosis and vascular inflammation, ${ }^{2,3}$ inflammatorymediated diseases such as arthritis, systemic lupus and sepsis. ${ }^{4}$ Moreover, platelets are involved in innate and adaptive immunity as well as in cancer metastasis. ${ }^{5-7}$

Since platelet transfusions have been proven to be able to reduce mortality from haemorrhage in patients with acute leukaemia in the 1950s, the use of the platelet transfusion has steadily grown to become an essential part of the treatment of major haemorrhagic complications associated with the management of haematological and oncological disorders. ${ }^{8,9}$ Today, more than 1.5 million platelet products are transfused in the USA and 2.9 million platelet products in Europe annually. ${ }^{9}$

Therapeutic platelet transfusions are widely accepted as indicated in children with severe thrombocytopenia and/or platelet dysfunction associated with active serious bleeding. ${ }^{8,10}$ Children thrombocytophenia can be caused by a number of disease processes such as decreased production (leukemia, systemic infection), increased destruction (idiopathic thrombocytopenia purpurea), medicationinduced (chemotherapy drugs) and others. ${ }^{11}$ The benefits of the therapeutic platelet transfusions can not be denied. However, due to increased concerns about their risks, such as transmission of various pathogens, fever, anaphylaxis and alloimmunization, the therapeutic platelet transfusion is being challenged as perhaps being without evidence base, and potentially inducing more harm than good for some patients. ${ }^{12}$
Therefore, the evaluation of the risk to benefits ratio of the platelets transfusions should be conducted. This study was conducted to evaluate risk factors of platelet refractoriness in pediatric patients who undewent platelet transfusions in Department of Pediatrics, Dr. Sardjito General Hospital, Yogyakarta.

\section{MATERIALS AND METHODS}

This was an observational study using casecontrol design aiming to evaluate sepsis, splenomegaly, severe bleeding, DIC (disseminated intravascular coagulation), and the history of platelet transfusion as the risk factors for platelet refractoriness in the children who underwent platelet transfusions and met the inclusion and exclusion criteria. The inclusion criteria were children aged 0-18 years, underwent platelet transfusion and thrombocyte assessment one hour or 16-24 hours or early morning of the next day after platelet transfusion. The exclusion criteria were children with ITP (immune thrombocytopenic purpurea) who received amphotericin B or heparin.

The case group consisted of patients who underwent platelet transfusion and had refractoriness to the platelet transfusion, whereas the control group consisted of patients who underwent platelet transfusion but had no refractoriness. Patients were considered having the refractoriness if they had the CCI (corrected count increment) of $<5,000 / \mu \mathrm{L}$ one hour after transfusion or $\hat{A} 2,500 / \mu \mathrm{L} 16-24$ hours or early morning of the next day after transfusion, whereas patients were considered having no refractoriness if they had the CCI of $\geq 5,000 /$ $\mu \mathrm{L}$ one hour after transfusion or $\geq 2,500 / \mu \mathrm{L}$ 16-24 hours or early morning of the next day after transfusion. ${ }^{12,15}$ Sample size was calculated using the formula to test the hypothesis of unpaired analysis. Therefore, the minimal number of subject in each group needed in this study was 76 . 
Characteristics subjects, clinical data including sepsis, splenomegaly, severe bleeding, DIC, and the history of the platelet transfusion were obtained from the medical records of each patient of Department of Pediatrics, Dr. Sardjito General Hospital, Yogyakarta from A ugust $1^{\text {st }}, 2010$ to September $30^{\text {th }}, 2011$. The study was approved by the Health Research Ethics Committee of the Faculty of Medicine, Universitas Gadjah Mada, Yogyakarta.

Bivariate analysis using Chi-square $\left(\chi^{2}\right)$ was used to evaluate sepsis, splenomegaly, severe bleeding, DIC, and the history of the platelet transfusion as risk factors of platelet refractoriness. Furthermore, multivariate analysis using logistic regression analysis was used to evaluate the relationship between the categorical independent variables (sepsis, splenomegaly, severe bleeding, DIC, and the history of the platelet transfusion) and dichotomous dependent variable (platelet refractoriness). Odds ratio (OR) with 95\% confidence intervals $(95 \% \mathrm{CI}$ ) was applied to assess the risk of the platelet refractoriness between the group with risk factors and the group without risk factors. A p value of less than 0.05 was considered to be significant.

\section{RESULTS}

Over a 13-month period from August $1^{\text {st }}$, 2010 until September $30^{\text {th }}$, 2011, data were collected from a total of 1403 platelet transfusion episodes in 464 patients in Dr. Sardjito General Hospital. During the platelet transfusion episodes, 86 refractory incidences and 86 non refractory incidences that met the criteria of study were identified. The refractory examination was based on CCI conducted 24 hours or early morning of the next day after transfusion.

The characteristics of patients who met the criteria of study are presented in TABLE 1 . No significant difference was observed in the number of patients based on gender in the refractory group compared to the non refractory group ( $\mathrm{p}=0.645)$. In additon, the number of patients based on age in the refractory group was also not significantly different compared to the non refractory group $(\mathrm{p}=0.229)$. However, all risk factors of platelet refractoriness namely sepsis, splenomegaly, severe bleeding, DIC, as well as the history of platelet transfusion observed in this study between refractory group and non refractory group were not significantly different $(p<0.05)$. Moreover, a patient with more than one risk factors of platelet refractoriness in same time in both refractory and no refractory groups was observed in this study. Sepsis together with splenomegaly, DIC together and/or heavy bleeding and platelet transfusions history could be confirmed in a patient.

TABLE 2 shows the bivariate analysis of the relatioship between the risk factors observed in this study and the occurrence of platelet fractoriness. Sepsis, splenomegaly, severe bleeding, DIC and the history of platelet transfusion significantly increased the occurrence of platelet refractoriness in pediatric patients who underwent platelet transfusion with different level $(\mathrm{p}<0.05)$. 
TABLE 1. The characteristics of patients

\begin{tabular}{|c|c|c|c|}
\hline \multirow{2}{*}{ Characteristics } & Refractory $(n=86)$ & Non refractory $(\mathrm{n}=86)$ & \multirow[b]{2}{*}{$\mathrm{p}$} \\
\hline & $\mathrm{n}(\%)$ & $\mathrm{n}(\%)$ & \\
\hline \multicolumn{4}{|l|}{ Gender } \\
\hline - Male & $50(58.1)$ & $47(54.7)$ & \multirow{2}{*}{0.645} \\
\hline - Female & $36(41.9)$ & $39(45.3)$ & \\
\hline \multicolumn{4}{|l|}{ Age (years) } \\
\hline - $0-5$ & $57(66.3)$ & $52(60.5)$ & \multirow{3}{*}{0.229} \\
\hline - $5<10$ & $21(24.4)$ & $17(19.8)$ & \\
\hline - $>10$ & $8(9.3)$ & $17(19.8)$ & \\
\hline \multicolumn{4}{|l|}{ Sepsis } \\
\hline - Yes & $72(83.7)$ & $40(46.5)$ & \multirow[b]{2}{*}{$0.000 *$} \\
\hline - No & $14(16.3)$ & $46(53.5)$ & \\
\hline \multicolumn{4}{|l|}{ Splenomegaly } \\
\hline - Yes & $27(31.4)$ & $12(14.0)$ & \multirow{2}{*}{$0.006 *$} \\
\hline - No & $59(68.6)$ & $74(86.0)$ & \\
\hline \multicolumn{4}{|l|}{ Heavy bleeding } \\
\hline - Yes & $58(67.4)$ & $17(19.8)$ & \multirow{2}{*}{$0.000 *$} \\
\hline - No & $28(32.6)$ & $69(80.2)$ & \\
\hline \multicolumn{4}{|l|}{ DIC } \\
\hline - Yes & $39(45.3)$ & $3(3.5)$ & \multirow{2}{*}{$0.000^{*}$} \\
\hline - No & $17(51.7)$ & $83(96.5)$ & \\
\hline \multicolumn{4}{|c|}{$\begin{array}{l}\text { History of platelet } \\
\text { transfusion }\end{array}$} \\
\hline - Yes & $61(70.9)$ & $27(31.4)$ & \multirow{2}{*}{$0.000 *$} \\
\hline - $\mathrm{No}$ & $25(29.1)$ & $59(68.6)$ & \\
\hline
\end{tabular}

DIC = disseminated intravascular coagulation; $*$ Significantly different $(p<0.05)$ 
TABLE 2. Bivariate analysis of the relationship between the risk factors and platelet refractoriness of pediatric patients who underwent platelet transfusion

\begin{tabular}{|c|c|c|c|c|}
\hline \multirow{2}{*}{ Characteristics } & $\begin{array}{l}\text { Refractory } \\
(\mathrm{n}=86)\end{array}$ & $\begin{array}{l}\text { Non refractory } \\
\qquad(\mathrm{n}=86)\end{array}$ & \multirow{2}{*}{ OR $(95 \% \mathrm{CI})$} & \multirow{2}{*}{$\mathrm{p}$} \\
\hline & $\mathrm{n}(\%)$ & $\mathrm{n}(\%)$ & & \\
\hline \multicolumn{5}{|l|}{ Sepsis } \\
\hline - Yes & $72(83.7)$ & $40(46.5)$ & 5.91 & \multirow{2}{*}{$0.000 *$} \\
\hline - No & $14(16.3)$ & $46(53.5)$ & $(2.90-12.05)$ & \\
\hline \multicolumn{5}{|l|}{ Splenomegaly } \\
\hline - Yes & $27(31.4)$ & $12(14.0)$ & 2.82 & \multirow{2}{*}{$0.006 *$} \\
\hline - No & $59(68.6)$ & $74(86.0)$ & $(1.31-6.04)$ & \\
\hline \multicolumn{5}{|l|}{ Heavy bleeding } \\
\hline - Yes & $58(67.4)$ & $17(19.8)$ & 8.04 & \multirow{2}{*}{$0.000^{*}$} \\
\hline - No & $28(32.6)$ & $69(80.2)$ & $(4.19-16.87)$ & \\
\hline \multicolumn{5}{|l|}{ DIC } \\
\hline - $\mathrm{Yes}$ & $39(45.3)$ & $3(3.5)$ & 22.95 & \multirow{2}{*}{$0.000 *$} \\
\hline - No & $47(54.7)$ & $83(96.5)$ & $(6.72-78.35)$ & \\
\hline \multicolumn{5}{|c|}{$\begin{array}{l}\text { History of platelet } \\
\text { transfusion }\end{array}$} \\
\hline - Yes & $61(70.9)$ & $27(31.4)$ & 5.33 & \multirow{2}{*}{$0.000 *$} \\
\hline - No & $25(29.1)$ & $59(68.6)$ & $(2.78-10.22)$ & \\
\hline
\end{tabular}

DIC = disseminated intravascular coagulation $*$ Significantly different $(p<0.05)$

TABLE 3 shows the multivariate analysis of the relatioship between the risk factors observed in this study and the occurrence of platelet fractoriness. Sepsis, splenomegaly, severe bleeding, DIC and the history of platelet transfusion were independent risk factors that increased the occurrence of platelet refractoriness in pediatric patients who underwent platelet transfusion with different level $(\mathrm{p}<0.05)$. 
TABLE 3. Multivariate analysis of the relationship between the risk factors and platelet refractoriness of pediatric patients who underwent platelet transfusion

\begin{tabular}{|c|c|c|c|c|}
\hline \multirow[t]{2}{*}{ Characteristics } & $\begin{array}{l}\text { Refractory } \\
\quad(\mathrm{n}=86)\end{array}$ & $\begin{array}{l}\text { Non refractory } \\
\qquad(\mathrm{n}=86)\end{array}$ & \multirow[t]{2}{*}{ OR $(95 \% \mathrm{CI})$} & \multirow{2}{*}{$\mathrm{p}$} \\
\hline & n $(\%)$ & n $(\%)$ & & \\
\hline \multicolumn{5}{|l|}{ Sepsis } \\
\hline - Yes & $72(83.7)$ & $40(46.5)$ & & \multirow{2}{*}{$0.019^{*}$} \\
\hline - No & $14(16.3)$ & $46(53.5)$ & $(1.19-7.32)$ & \\
\hline \multicolumn{5}{|l|}{ Splenomegaly } \\
\hline - Yes & $27(31.4)$ & $12(14.0)$ & 3.94 & \multirow{2}{*}{$0.000 *$} \\
\hline - No & $59(68.6)$ & $74(86.0)$ & $(2.20-16.00)$ & \\
\hline \multicolumn{5}{|l|}{ Heavy bleeding } \\
\hline - Yes & $58(67.4)$ & $17(19.8)$ & 3.53 & \multirow{2}{*}{$0.008^{*}$} \\
\hline - No & $28(32.6)$ & $69(80.2)$ & $(1.40-8.89)$ & \\
\hline \multicolumn{5}{|l|}{ DIC } \\
\hline - Ycs & $39(45.3)$ & $3(3.5)$ & 5.41 & \multirow{2}{*}{$0.021 *$} \\
\hline - No & $47(54.7)$ & $83(96.5)$ & $(1.29-6.31)$ & \\
\hline \multicolumn{5}{|c|}{$\begin{array}{l}\text { History of platelet } \\
\text { transfusion }\end{array}$} \\
\hline - Yes & $61(70.9)$ & $27(31.4)$ & 2.84 & \multirow{2}{*}{$0.010^{*}$} \\
\hline - No & $25(29.1)$ & $59(68.6)$ & $(1.28-6.31)$ & \\
\hline
\end{tabular}

DIC $=$ disseminated intravascular coagulation $*$ Significantly different $(p<0.05)$

\section{DISCUSSION}

Platelet refractoriness is a result of the shortened survival of platelets caused by factors of non-immunologic and/or immunologic origins. Non-immunologic causes involve sepsis, fever, splenomegaly, bone marrow and peripheral blood progenitor cell transplantation, disseminated intravascular coagulation, graftversus-host disease, vaso-occlusive diseases, drug induced thrombocytopenia and hemorrhages. ${ }^{11,12}$ The immunologic causes involve antibodies against the ABO system, human leukocyte antigen (HLA) and/or human platelet antigen (HPA) present on the membrane of donor platelets. ${ }^{13-15}$

In this study, the causes of platelet refractoriness in pediatric patients who undewent platelet transfusions were evaluated. Sepsis, splenomegaly, severe bleeding, DIC and the history of platelet transfusion have been proven as independent risk factors that increased the occurrence of platelet refractoriness in pediatric patients.

Sepsis increased the occurrence of platelet refractoriness 3 times higher $(\mathrm{OR}=2.96)$ than in children without sepsis. These results are similar to studies conducted in adult patients that found the relative risk of platelet transfusion refractoriness was 2.73. ${ }^{11}$ Platelet refractoriness in patients with sepsis occurs through the activation of prothrombin by cytokines. ${ }^{16}$ Lipopolysaccharides found in the outer membrane of bacteria acts as endotoxins and activates platelets directly. ${ }^{17}$ In addition, 
hematophagocyitosis has been reported as a cause of thrombocytopenia in sepsis, although its mechanisms remain unclear. It is thought that macrophage plays an important role in thrombocytopenia in sepsis. The macrophagecolony-stimulating factor (M-CSF) is overproduced in the sepsis syndrome, particularly when hemophagocytosis is present. ${ }^{18}$

Meanwhile, the risk of platelet refractoriness increased 4 times $(\mathrm{OR}=3.94)$ in pediatric patients with splenomegaly in this study. Platelet refractoriness in patients with splenomegaly occurs due to the increase of platelet sequestration that increases proporsionally with the enlargement of splen. ${ }^{19}$ The risk of platelet refractoriness due to splenomegaly reported in this study was higher than another study conducted in adult patients which reported that platelet refractoriness was observed in $25 \%$ of the 533 patients who underwent splenectomy. ${ }^{11}$ The decrease of the platelet refractoriness incidence in patients who underwent spelectomy caused no platelet sequestration, whereas in patients who underwent no splenectomy, up to one third of platelet transfused would be sequestrated. ${ }^{19}$ The risk of platelet refractoriness in pediatric patients seems to be higher than in adult patients. It is becaused the blood volume in the spleen of children is relatively higher than those in adults. Moreover, the number of platelets in the spleen is associated with increasing age and weight. ${ }^{19}$

Severe bleeding increased the occurrence of risk of platelet refractoriness 3.5 times higher $(\mathrm{OR}=3.52)$ compared to those without severe bleeding, in this study. The risk of platelet refractoriness due to severe bleeding reported in this study was higher than another study conducted in adult patients which reported that RR of platelet refractoriness due to severe bleeding was $2.71 .{ }^{11}$ Platelet refractoriness in patients with severe bleeding may be caused by activation of coagulation cascade in order to stop bleeding. Platelets are activated directly at the bleeding site by endothelial damage and indirectly through the clotting cascade. In severe bleeding, various cytokines and tissue factors as well as lipid and phospholipid of tissue are released into the circulation that causes the clotting cascade. ${ }^{8,20}$

Disseminated intravascular coagulation increased the occurrence of risk of platelet refractoriness 5.4 times higher $(\mathrm{OR}=5.41)$ compared to those without DIC, in this study. This result was similar with another study which reported the RR of platelet refractoriness of children and adult patients with DIC was 5.01. ${ }^{21}$ In DIC, the massive prothrombin activation and the various cytokine release lead to platelet activation directly. In addition, massive endothelial damage in DIC will also activate the clotting cascade that also involves the platelet activation. ${ }^{22}$ Bacterial surface componenets such lipopolysaccharides and endotoxins also activate platelets. ${ }^{23}$ The stimulation of various platelet activation pathways at the same time can result in the development of DIC as the strongest risk factor for the platelet refractoriness incidence. ${ }^{24}$

The history of platelet transfusion increased the risk of platelets refractoriness almost 3 times higher $(\mathrm{OR}=2.84)$ compared to patients without the history of platelet transfusion, in this study. This result was higher than another study that reported that the RR of platelets refractoriness in patients having the history of platelet transfusion was 1.56. ${ }^{11}$ The different results obtained from the two studies might be associated with platelet factors used. Leukoreduction of platelet was used in previous study. It could reduce the platelet refractoriness occurence from $30 \%$ to $5 \%$. The platelet refractoriness occurence in patients having the history platelet transfusion is thought to be mediated by the formation of the HPA (human platelet antigen) and HLA (human leucocyte antigen) antibodies 
through thrombocyte. The HLA formation is 10 times higher than HPA formation. Therefore, the use of leukoreduction of platelet can reduce the occurence of platelet refractoriness. ${ }^{10}$

\section{CONCLUSION}

It can be concluded that sepsis, splenomegaly, severe bleeding, DIC, and the history of platelet transfusion are the risk factors of platelet refractoriness in pediatric patients.

\section{ACKNOWLEDGEMENTS}

Authors would like to thank Head of Department of Pediatrics, Faculty of Medicine, Universitas Gadjah Mada/Dr. Sardjito General Hospital for his permission in conducting this study.

\section{REFERENCES}

1. Jurk K, Kehrel BE. Platelets: physiology and biochemistry. Semin Thromb Hemost 2005; 31(4):381-92.

2. Nofer JR, Brodde MF, Kehrel BE. High-density lipoproteins, platelets and the pathogenesis of atherosclerosis. Clin Exp Pharmacolo Physiol 2010; 37(7):726-35.

3. Projahn D, Koenen RR. Platelets: key players in vascular inflammation. J Leukoc Biol 2012; 92(6):1167-75.

4. Katz JN, Kolappa KP, Becker RC. Beyond thrombosis: the versatile platelet in critical illness. Chest 2011; 139(3):658-68.

5. Semple JW, Freedman J. Platelets and innate immunity. Cell Mol Life Sci 2010; 67(4):499511.

6. Vieira-de-Abreu A, Campbell RA, Weyrich AS, Zimmerman GA. Platelets: versatile effector cells in hemostasis, inflammation, and the immune continuum. Semin Immunopathol 2012; 34(1):530.

7. Palumbo JS, Talmage KE, Massari JV, La Jeunesse CM, Flick MJ, Kombrinck KW, et al. Platelets and fibrin(ogen) increase metastatic potential by impeding natural killer cell-mediated elimination of tumor cells. Blood 2005; 105(1):178-85.
8. Stroncek DF \& Rubella P. Platelet transfusions. Lancet 2007; 370(9589):427-38.

9. Hod E, Schwartz J. Platelet transfusion refractoriness. Br J Haematol 2008; 142(3):34860.

10. Refaai MA, Phipps RP, Spinelli SL, Blumberg N. Platelet transfusions: impact on hemostasis, thrombosis, inflammation and clinical outcomes. Thromb Res 2011; 127(4):287-91.

11. Slichter SJ, Davis K, Enright H, Braine H, Gernsheimer T, Kao KJ, et al. Factors affecting post transfusion platelet increments, platelet refractoriness, and platelet transfusion intervals in thrombocytopenic patients. Blood 2005; 105(10):4106-14.

12. Cameron B, Rock G, Olberg B, Neurath D. Evaluation of platelet transfusion triggers in a tertiary-care hospital. Transfusion 2007; 47(2):206-11.

13. Shehata N, Tinmouth A, Naglie G, Freedman J, Wilson K. ABO-identical versus nonidentical platelet transfusion: a systematic review. Transfusion 2009;49(11):2442-53.

14. Delaflor-Weiss E, Mintz PD. The evaluation and management of platelet refractoriness and alloimmunization. Transfus Med Rev. 2002;14(2):180-96.

15. Tinmouth AT, Semple E, Shehata N, Branch DR. Platelet immunopathology and therapy: a Canadian Blood Services Research and Development Symposium. Transfus Med Rev 2006;20 (4):294314.

16. Levi M \& Lowenberg EC. Thrombocytopenia in critically ill patients. Semin Thromb Hemost 2008; 34(5): 417-24.

17. Levi M. Platelets in sepsis. Hematology 2005; 10 (Suppl 1):129-31.

18. François B, Trimoreau F, Vignon P, Fixe P, Praloran V, Gastinne H. Thrombocytopenia in the sepsis syndrome: role of hemophagocytosis and macrophage colony-stimulating factor. Am J med 1997; 103(2):114-20.

19. Poala SB, Bisogno G, Colombatti R. Thrombocytopenia and splenomegaly: an unusual presentation of congenital hepatic fibrosis. Orphanet J Rare Dis 2010;5:4. Doi: 10.1186/ 1750-1172-5-4.

20. Drews RE \& Weinberger SE. Trombocitopenic disorders in critically ill patients. Am J Respir Crit Care Med 2000; 162(2 Pt 1); 347-51. 
21. Fabris F, Soini B, Sartori R, Randi ML, Luzatto G, Girolami A. Clinical and laboratory factors that affect the post-transfusion platelet increment. Transfus Sci 2000; 23(1):63-8.

22. Levi M \& Meijers JC. DIC: Which laboratory tests are most useful. Blood Rev 2011; 25(1):33-7.
23. Bick LR. Disseminated intravascular coagulation current concepts of etiology, pathophysiology, diagnosis, and treatment. Hematol Oncol Clin North Am 2003; 17(1):149-76.

24. Saba HI \& Morelli GA. The pathogenesis and management of disseminated intravascular coagulation. Clin Adv Hematol Oncol 2006; 4(12):919-26. 